\title{
STUDENTS' DIGITAL LITERACY AND COLLABORATION ABILITIES: AN ANALYSIS IN SENIOR HIGH SCHOOL STUDENTS
}

\author{
Lilis Purnamasari $^{1^{*}}$, Kartini Herlina ${ }^{2}$, I Wayan Distrik ${ }^{3}$, Doni Andra ${ }^{4}$ \\ 1,2,3,4 Department of Physics Education, Postgraduate Program, Universitas Lampung, Indonesia \\ *Corresponding author: lilispurnamasari1212@yahoo.com
}

\begin{tabular}{|c|c|}
\hline Article Info & ABSTRACT \\
\hline Article history: & This study aims to describe and analyze the level of digital literacy \\
\hline $\begin{array}{l}\text { Received: November } 14, \\
2020\end{array}$ & $\begin{array}{l}\text { and collaboration skills of students. The research method used a } \\
\text { quantitative descriptive survey with a research instrument in the } \\
\text { form of a questionnaire. The study involved } 10 \text { physics teachers and }\end{array}$ \\
\hline Accepted: March 25, 2021 & 105 high school students in Lampung Province. The results showed \\
\hline Published: March 31, 2021 & that the digital literacy of students was in the sufficient category \\
\hline Keywords: & $\begin{array}{l}\text { with the achievement percentage of } 54.68 \% \text {, while the collaborative } \\
\text { abilities of students were in the poor category with the achievement }\end{array}$ \\
\hline $\begin{array}{l}\text { Collaboration ability } \\
\text { Digital literacy }\end{array}$ & $\begin{array}{l}\text { percentage of } 39.17 \% \text {. Digital literacy has not been maximally } \\
\text { achieved and the ability to collaborate in students is influenced by } \\
\text { the lack of efforts of students to use the internet as a learning } \\
\text { resource and the lack of student-centered learning. }\end{array}$ \\
\hline
\end{tabular}

\section{LITERASI DIGITAL DAN KEMAMPUAN KOLABORASI: ANALISIS PADA SISWA SEKOLAH MENENGAH ATAS}

\section{Kata Kunci: \\ Kemampuan berkolaborasi \\ Literasi digital}

\begin{abstract}
ABSTRAK
Penelitian ini bertujuan untuk mendeskripsikan dan menganalisis tingkat literasi digital dan kemampuan berkolaborasi peserta didik. Metode penelitian menggunakan survei deskriktif kuantitatif dengan instrumen penelitian berupa kuesioner. Penelitian melibatkan 10 guru fisika dan 105 peserta didik SMA di Provinsi Lampung. Hasil penelitian menunjukkan bahwa literasi digital peserta didik, berada pada kategori cukup dengan persentase ketercapaian sebesar 54,68\%, sedangkan kemampuan berkolaborasi peserta didik berada pada kategori kurang dengan persentase ketercapaian sebesar $39,17 \%$. Belum maksimalnya ketercapaian literasi digital dan kemampuan berkolaborasi dalam diri peserta didik, dipengaruhi oleh belum maksimalnya usaha peserta didik memanfaatkan internet sebagai sumber belajar dan belum terlaksananya pembelajaran yang berpusat kepada peserta didik.
\end{abstract}


report data published by Kemp in 2020 on the wearesocia.com page, also shows that internet users in the world has increased by more than 7\% since 2019.[5].

Accessing information on the internet is inseparable from literacy activities, namely the process of processing information through reading, writing and counting activities to obtain precise and accurate information [6]. The Skills Matter report released by the Organization for Economic Cooperation and Development (OECD) 2016, shows that based on the Program for the International Assessment of Adult Competencies (PIAAC) test, it is known that Indonesia's adult literacy rate is in the lowest position of the 40 countries participating in this program[7]. Based on these data, it is necessary to make efforts to increase the literacy of Indonesian citizens, especially during the use of the internet as a means of accessing information.

One of the efforts to increase literacy is carried out in education by making digital literacy an important competency in the curriculum, which must be mastered by students. Digital literacy is a life skill that not only involves the ability to use technological devices but also the ability to socialize and the ability to have attitudes, to think critically, creatively, and inspire in interpreting information through technological devices [8] [9], [10]. The national education curriculum expects students to be able to find material concepts that they learn from various learning sources, one of which is the internet. Although students are generally considered to be smart in internet technology, many of them have not made effective use of the internet in learning [5]-[6].

Some students only copy and paste text in working on their assignments/questions, they just answered it by typing the questions into the Google search engine without trying to understand more deeply the concept [13]. This happens because the assignment given by the teacher has not directed students to practice higher-order thinking skills (Higher Of Thinking Skills / HOTS). The questions in the task tend to be at the 'applying' level, so that students are only trained to develop skills using word matching strategies. The word matching strategy is one of the learning strategies that makes students tend to be passive in learning [14]. The passivity of students in learning is also influenced by the learning model applied by the teacher. The curriculum requires teachers to be able to apply several learning models, namely, discovery learning, inquiry learning, problem based learning and project based learning [15]. These learning models direct the creation of student-centered learning, where students learn socially in small groups to practice various abilities, including the ability to collaborate [16].

Collaboration in learning is defined as the reciprocal involvement of students in a coordinated effort to solve a problem together [17]. However, in the implementation of learning, the teacher has not maximally played a role as a good facilitator to be able to achieve the effectiveness of collaborative learning, and students have not been consistent in being able to work well together [18]. This becomes an obstacle in growing the collaborative abilities of students [19].

Based on the findings of the problems above, the researcher is interested in conducting a study on digital literacy assessment and the collaborative ability of students from the point of view of teachers and students. This research is very important to be able to describe and analyze the level of digital literacy and the collaborative abilities of students.

\section{METHOD}

This type of research is quantitative descriptive survey research with data collection instruments using a questionnaire. The research was conducted in several high schools in Lampung province on the subject of physics with the research flow as shown in Figure 1. 


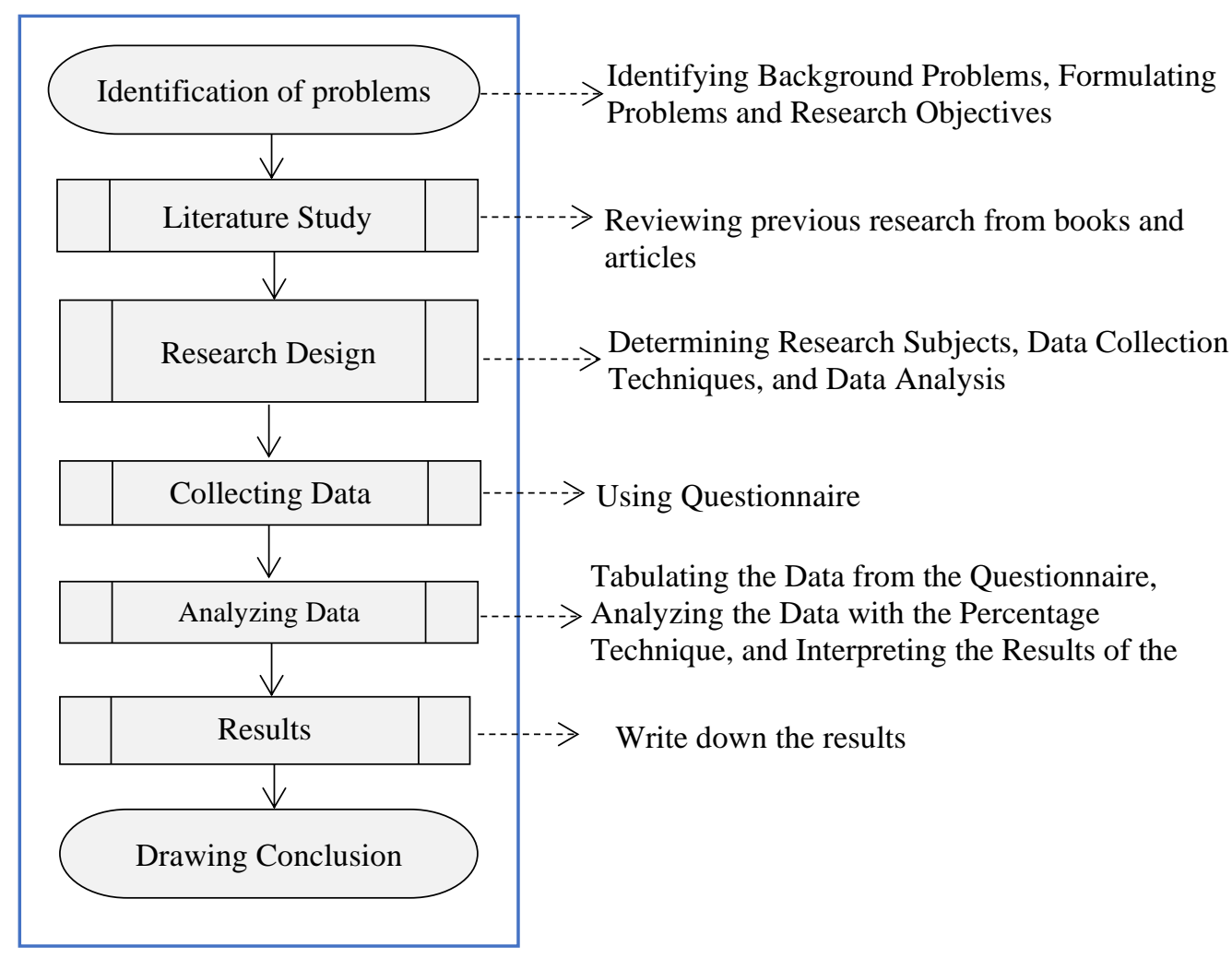

Figure 1. Research Flow

The questionnaire given to teachers and students contains questions to see the physics learning process and determine the level of digital literacy and students' collaboration skills. The questionnaire instrument used in the study consisted of openended questions and a Likert-scale questionnaire. Likert scale is a scale used to measure attitudes, opinions, and perceptions of a person or group of people about a social phenomenon [20]. The lowest scale used is 1 and the highest is 5, as presented in Table 1.

Table 1. Likert Scale Categories in the Questionnaire [20], [21]

\begin{tabular}{ccc}
\hline Scale & \multicolumn{2}{c}{ Category } \\
\cline { 2 - 3 } & Digital Literacy & Collaboration \\
\hline 1 & Strongly Disagree & Never \\
2 & Disagree & Rarely \\
3 & Neutral & Sometimes \\
4 & Agree & Often \\
5 & Strongly agree & Always \\
\hline
\end{tabular}

The data from teacher and student questionnaires were then analyzed using quantitative descriptive analysis and made in the form of percentage (\%). The percentage value was calculated using formula (1) as follows:

Information:

$$
\mathrm{P}=\frac{\mathrm{F}}{\mathrm{N}} \times 100 \%
$$

$\mathrm{P}=$ Percentage

$\mathrm{F}=$ Total score obtained

$\mathrm{N}=$ Maximum score. [22] 
Especially for digital literacy data and students' collaboration skills, the percentage of the questionnaire results is interpreted into the categories according to Table 2.

Table 2. Interpretation of Students' Perceptions About Digital Literacy and Collaboration Ability

\begin{tabular}{cc} 
Percentage $(\boldsymbol{\%})$ & Category \\
\hline $0-19,99$ & Very Poor \\
$20-39,99$ & Poor \\
$40-59,99$ & Average \\
$60-79,99$ & Good \\
$80-100$ & Very good \\
\hline
\end{tabular}

\section{RESULTS AND DISCUSSION}

The research data consisted of 3 data, namely, information related to the physics learning process, digital literacy, and the collaborative abilities of students. The following are details of the research results related to the perceptions of students and teachers about the physics learning process. The data collection of the physics learning process was carried out using a questionnaire that was made by adopting several indicators of effective learning.[24].

Table 3. Results of Student Questionnaires about Physics Learning Process [24]

\begin{tabular}{|c|c|c|}
\hline No & & Question \\
\hline 1 & $80,95 \%$ & $\begin{array}{l}\text { Students have difficulty in applying formulas to answer questions and understand } \\
\text { physics concepts }\end{array}$ \\
\hline 2 & $74,28 \%$ & The teacher links the concepts learned with phenomena in everyday life \\
\hline 3 & $42,85 \%$ & Students consider rotational dynamics and fluid dynamics to be difficult material \\
\hline 4 & $47,61 \%$ & Students discuss groups to answer questions in the textbook \\
\hline 5 & $79,04 \%$ & Students do not understand what they should do when studying in groups \\
\hline 6 & $90,47 \%$ & Students stated that only some members work while studying in groups \\
\hline 7 & $95,23 \%$ & Students expect learning that does not only discuss formulas \\
\hline 8 & $85,71 \%$ & Students expect contextual learning (linking material with phenomena in everyday life) \\
\hline 9 & $93,33 \%$ & Students expect learning with experimental activities \\
\hline 10 & $100 \%$ & Students expect learning that displays the application video of the material \\
\hline 11 & $59,04 \%$ & $\begin{array}{l}\text { Students state that the teacher facilitates learning with Worksheets when learning } \\
\text { offline }\end{array}$ \\
\hline 12 & $29,52 \%$ & $\begin{array}{l}\text { Students state that the Student Worksheet given by the teacher has directed to solve a } \\
\text { problem and conduct experiments in groups when learning offline }\end{array}$ \\
\hline 13 & $36,91 \%$ & $\begin{array}{l}\text { Students state that there is a guide for the task of making work in the Student } \\
\text { Worksheet }\end{array}$ \\
\hline 14 & $88,57 \%$ & $\begin{array}{l}\text { Students state that Student Worksheets have not led to collecting information on the } \\
\text { internet in the problem-solving process }\end{array}$ \\
\hline 15 & $38,09 \%$ & Students use electronic books and digital media in learning physics \\
\hline 16 & $75,23 \%$ & $\begin{array}{l}\text { Students stated that during online learning, the teacher gave assignments via the } \\
\text { Whatsapp group which were then completed by looking for answers in books and the } \\
\text { internet. }\end{array}$ \\
\hline 17 & $68,57 \%$ & Students stated that during online learning they were never given group assignments \\
\hline
\end{tabular}

Table 3 shows the complaints of students that they have difficulty applying formulas in solving problems and understanding the concepts of physics. Students also consider that rotational dynamics and fluid dynamics are two difficult topics to understand. When implementing physics learning, students expect contextual learning by using visual media (learning that links material with phenomena in everyday life through video shows). In addition, students also expect learning that does not only discuss formulas, but expects learning that leads students to carry out experiments in groups. 
The results of the questionnaire also showed that group learning activities were not often applied in learning physics, so that students were not used to practicing their collaborative skills. Many of the students have not been actively collaborating, this can be seen from the high percentage of questionnaire answers which state that only some group members work while studying in groups. The passivity of students to work together is caused by the large number of students who feel they do not understand what they should do when studying in groups.

Some teachers have attempted to direct student learning activities by facilitating offline learning through the use of Student Worksheets. However, the worksheets used have not fully led students to solve a problem, conduct experiments in groups, make a product, or direct students as generation $\mathrm{Z}$ to collect digital information from the internet.

During the current pandemic, students are required to learn with an online system, which raises the need to take advantage of digital technology tools that students have to find digital information as a learning resource. However, in practice the teacher has not fully directed students to learn together in small groups to solve a problem through investigation activities and the use of digital information on the internet.

The description of the learning process above shows that learning has not been running effectively. There are 5 indicators of effective learning, including 1) management of learning implementation; 2) communicative process; 3) students' responses; 4) learning activities and 5) learning outcomes. When the five indicators have not been implemented properly, it is necessary to find the cause in order to find a solution [24]. The independent learning process by students must be directed and facilitated with teaching materials that effectively help students learn independently through various learning resources [25]. One of the teaching materials that can direct students to learn effectively is the Student Worksheet [26].

An explanation of the physics learning process based on the results of the students' questionnaire in Table 3, is strengthened by the results of the teacher's questionnaire about the physics learning process in Table 4.

Table 4. Results of the Teacher's Questionnaire for the Physics Learning Process [24]

\begin{tabular}{|c|c|c|}
\hline No & & Statement \\
\hline 1 & $80 \%$ & $\begin{array}{l}\text { The teacher stated students have difficulty learning physics (understanding physics } \\
\text { concepts, applying physics formulas, and performing mathematical arithmetic } \\
\text { operations) }\end{array}$ \\
\hline 2 & $40 \%$ & The teacher used the practical and experimental methods in groups in learning physics \\
\hline 3 & $90 \%$ & The teacher stated that in group learning students are asked to discuss solving a problem \\
\hline 4 & $70 \%$ & The teacher stated that there was a set time limit for students to discuss \\
\hline 5 & $90 \%$ & The teacher stated that students found it difficult to contribute to giving ideas in groups \\
\hline 6 & $50 \%$ & The teacher stated that students had difficulty managing time in group discussions \\
\hline 7 & $70 \%$ & The teacher stated that students found it difficult to find answers to problems \\
\hline 8 & $70 \%$ & $\begin{array}{l}\text { The teacher stated that students had difficulty hearing opinions and helped group } \\
\text { members }\end{array}$ \\
\hline 9 & $70 \%$ & The teacher often raises questions at the application level in the assessment instrument \\
\hline 10 & $10 \%$ & $\begin{array}{l}\text { Teachers did online learning through videos and pictures accompanied by literacy } \\
\text { assignments }\end{array}$ \\
\hline 11 & $20 \%$ & $\begin{array}{l}\text { The teacher conducted online learning by providing modules containing teaching } \\
\text { material, sample questions, and practice questions that are sent via the Whatsapp group }\end{array}$ \\
\hline 12 & $40 \%$ & $\begin{array}{l}\text { The teacher conducted online learning through the Whatsapps group, where students were } \\
\text { given a stimulus in the form of a picture or ppt about the material, then the students were } \\
\text { asked to work on an assignment in the form of a description item }\end{array}$ \\
\hline 13 & $30 \%$ & $\begin{array}{l}\text { The teacher did online learning by giving assignments that must be done in groups by } \\
\text { students via the Whatsapp group }\end{array}$ \\
\hline
\end{tabular}


$14 \quad 60 \%$ The teacher stated that during Online learning, students were not disciplined in collecting assignments and did not attend the Physics learning schedule

$15 \quad 10 \%$ The teacher stated that during online learning the group learning technique was carried out by students working on the question link by including evidence of a joint video call and a screen shoot chat of students when discussing problem-solving

$1620 \% \quad$ The teacher stated that during online learning, group learning was carried out by asking students to form groups then discussing to answer questions, then collecting the answers accompanied by evidence of chat screenshots of discussion activities

$1780 \%$ The teacher stated that the positive impact of online learning was that teachers were more creative in using IT and students began to learn to get used to using android to learn and search for information on the internet

$1860 \%$ The teacher stated that the physics material for class XI that was difficult for students to understand was thermodynamics and dynamic fluids

$19 \quad 40 \%$ The teacher used Student Worksheets in learning physics

$2030 \%$ The teacher stated the material arrangement in the Student Worksheet in accordance with the Basic Competence (KD) to be achieved

$2120 \% \quad$ The teacher stated that the experimental guide is available in the Student Worksheet

$22 \quad 20 \%$ The teacher stated that there is a design guide in the Student Worksheet for making a work that applies the concepts learned

$23 \quad 100 \%$ The teacher stated that the Student Worksheet had a role to further direct the learning activities of students

$24 \quad 30 \%$ The teacher understood the problem-based learning model appropriately

$25 \quad 25 \%$ The teacher stated that the Student Worksheet used was integrated with the stages of the Problem Based Learning model

$26 \quad 100 \%$ The teacher agreed to develop problem-based student worksheets to foster digital literacy and collaboration skills.

The teacher's perspective on the implementation of physics learning in Table 4, shows some problem findings. The teacher stated that many students had difficulty understanding the concepts of physics, applying physics formulas, and performing mathematical arithmetic operations. When the implementation of physics learning is carried out offline, the teacher has used practical and experimental methods in a group learning system with a certain time limit. However, in its implementation, the group learning has not run optimally. Many of the students do not understand the tasks they have to do. Students also experience difficulties when studying in groups including, it is difficult to contribute to giving ideas, it is difficult to manage time, it is difficult to find answers to problems and it is difficult to be able to help group members.

The assessment made by the teacher to assess student learning outcomes is more predominantly composed of questions at the 'applying' level. This shows that the teacher has not maximally trained the HOTS of students by bringing up questions at the reasoning level. As long as learning is carried out online, the teacher is more dominant in carrying out learning through the Whatsapps group, by means of which students are given a stimulus in the form of a picture or PowerPoint file about the material, then students are asked to work on assignments in the form of item description questions. The task given by the teacher directs students to learn individually. As for when students are given group assignments, students are asked to form groups then discuss answering questions, then collect answers accompanied by evidence of chat screenshots and video discussion activities.

The implementation of Online learning that is currently being carried out has an impact on the learning activities of students. Students begin to get used to using their smartphones for learning. However, students have not been maximally directed to search for information on the internet, conduct experiments, and design simple works in the process of finding concepts or building knowledge. 
The description of the initial state of the learning process above shows several problems in the physics learning process, including the low level of student collaboration skills, and the inadequate use of the internet in the information search process. The findings of these problems are reinforced by preliminary data regarding the level of digital literacy and the ability to collaborate with students based on the results of the answers to the students' questionnaires, which we present in Table 5 and Table 6.

Table 5. Results of Student Questionnaires for Digital Literacy

\begin{tabular}{clcc}
\hline No & Digital Literacy Components & Percentage (\%) & Category \\
\hline 1 & Internet searching & 57,82 & average \\
2 & Hypertextual Navigation & 50,9 & average \\
3 & Content Evaluation & 52,2 & average \\
4 & Knowledge Assembly & 57,83 & average \\
& Average & 54,68 & average \\
\hline
\end{tabular}

Table 5, shows the digital literacy level of students as seen from the 4 components. These components are, 1) Internet Searching, the ability to search for information on the internet; 2) Hypertextual Navigation, knowledge of how the web works; 3) Content Evaluation, the ability to analyze background information and 4) Knowledge Assembly, the ability to double-check the information obtained and the ability to compile the sources of information obtained [5].

The data from the students' questionnaire for digital literacy in Table 5 shows that the average digital literacy component is in the sufficient category. The lowest digital literacy component is in the Hypertextual Navigation component. Hypertextual Navigation is a capability related to knowledge of how the web works, including knowledge of bandwidth, http, html, and url, as well as the ability to understand the characteristics of web pages [11]. The low component of the Hypertextual Navigation is because when accessing information, students are not used to using a credible website in learning and do not try to understand more deeply the material they learn when accessing the information on the internet. This is consistent with the problem findings in the introduction to this article. Furthermore, in this study, the researcher also collected data related to the collaborative abilities of students, which the researchers presented in Table 6 .

Table 6. Results of Student Questionnaires for Collaboration Ability

\begin{tabular}{clcc}
\hline No & Collaborative Ability Components & Percentage $(\%)$ & Category \\
\hline 1 & Contribution & 41,52 & Average \\
2 & Time management & 36,38 & Less \\
3 & Solution to problem & 39,62 & Less \\
4 & Cooperation & 45,52 & Average \\
5 & Investigation technique & 35,62 & Less \\
6 & Synthesis Average & 36,38 & Less \\
& & 39,17 & Less \\
\hline
\end{tabular}

Table 6 shows the results of the students' questionnaire for the level of collaboration skills seen from the 6 components. These components consist of, 1) Contributions, providing ideas or ideas in participating in group discussion activities; 2) Time management, managing time to complete group assignments on time; 3) Problem solving, trying to solve problems; 4) Working with others, listening to group colleagues' opinions / ideas and helping to complete group assignments; 5) Research techniques, looking for content or theory sources to answer/solve problems and 5) Synthesis, compiling complex ideas into a structural arrangement [16][27]. 
The data from the questionnaire results in Table 6 show that the average level of ability to collaborate is in the poor category. This shows that it is very necessary to hold an effort to be able to improve the collaborative abilities of students. The lowest component of students' collaborative abilities is in the component of the investigation technique. The investigation component is a component related to the ability of students to collect information and analyze information to find solutions/answers to problems that arise in learning [28].

However, the investigative activities that have been implemented have not been directed and systematic, so that it makes students feel difficulty in collaborating, this can be seen from the data analysis of the results of the learning process questionnaire in Table 3.The low ability of students to carry out investigations shows that there is still a lack of students' efforts to solve them. a problem. The problem-solving process in learning can run systematically if the learning process is done effectively, one of which is supported by the use of teaching materials that actively support students to be active in learning untuk meningkatkan kemampuannya [26] [29]. So that in the future, an effort is needed to foster the collaborative abilities of students.

Based on the results of the analysis of the answers to the students' and teachers' questionnaires about the physics learning process, the average value of the digital literacy components and the students' collaboration skills above, shows that students do not have a good digital literacy nor collaboration skill. This is in accordance with the results of previous research, which states that the ability to collaborate and digital literacy of students as 21 st-century skills are in the poor category, so it is necessary to make an effort to improve the quality of learning that applies various methods or learning strategies that are suitable to help students grow. digital literacy and collaboration skills [19] [30].

\section{CONCLUSION}

Based on the research results, it is concluded that the digital literacy of students is in the sufficient category with a percentage of $54.68 \%$, while the collaborative ability of students is in the poor category with a percentage of $39.17 \%$. Some of the factors that cause low literacy and digital collaboration skills are 1) the use of the internet as an inadequate learning resource for building knowledge; 2) the teacher's role is not optimal to facilitate student-centered learning; 3) learning assessment has not used the HOTS level; and 4) the implementation of collaborative learning has not been carried out intensively. Based on the findings of these problems, it is suggested to develop teaching materials that can effectively foster students' digital literacy and collaboration ability.

\section{REFERENCES}

[1] N. Pratiwi and N. Pritanova, "Pengaruh Literasi Digital Terhadap Psikologis Anak Dan Remaja,” Semantik, vol. 6, no. 1, p. 11, 2017.

[2] E. Nurjanah, A. Rusmana, and A. Yanto, "Hubungan Literasi Digital dengan Kualitas Penggunaan E-Resources," Lentera Pustaka J. Kaji. Ilmu Perpustakaan, Inf. dan Kearsipan, vol. 3, no. 2, p. 117, 2017.

[3] B. Wright, "Top 10 Benefits of Digital Literacy.Web Percent," wordpress.com, 2015. [Online]. Available: https://wepercent.wordpress.com/2012/06/16/top-10benefits-of-digtal-literacy. [Accessed: 12-Jun-2019].

[4] APJII, "Penetrasi dan Profil Perilaku Pengguna Internet Indonesia," Asosiasi Penyelenggara Internet Indonesia, 2019. [Online]. Available: https://apjii.or.id/content/read/104/418/BULETIN-APJII-EDISI-40---Mei-2019. [Accessed: 12-Jun-2019]. 
[5] S. Kemp, "Digital Around The World in April 2020," We are social, 2019. [Online]. Available: https://wearesocial.com/blog/2020/04/digital-around-the-world-in-april2020. [Accessed: 10-Jun-2019].

[6] D. Hanelahi and K. Atmaja, "Literasi Digital Dalam Peningkatan Kompetensi Peserta Didik Distance Learning Di Homeschooling," J. Pendidik. Untuk Semua, vol. 4, no. 4, 2020.

[7] OECD, "Skills Matter: Further Results from the Survey of Adult Skills," OECDOECD Publishing, 2016. [Online]. Available: https://doi.org/10.1787/9789264258051-en. [Accessed: 10-Jun-2019].

[8] UNESCO, "Digital Literacy In Education," UNESCO Institute, 2011. [Online]. Available: https://iite.unesco.org. [Accessed: 10-Jun-2019].

[9] A. Gruszczynska and R. Pountney, "Developing the Concept of Digital Literacy in the Context of Schools and Teacher Education," Enhancing Learn. Soc. Sci., vol. 5, no. 1, pp. 25-36, 2013.

[10] P. Phuapan, C. Viriyavejakul, and P. Pimdee, "Digital Literacy Skill of Students in Public Higher Education Institutes," in The Asian Conference on Technology in the Classroom, pp. 1-10, 2015.

[11] J. A. Greene, S. B. Yu, and D. Z. Copeland, "Measuring Critical Component of Digital Literacy and their Relationships with Learning," Comput. Educ., 2014.

[12] Y. Ting, "Internet and Higher Education Tapping into students ' digital literacy and designing negotiated learning to promote learner autonomy," Internet High. Educ., vol. 26, pp. 25-32, 2015.

[13] E. E. Latifah and J. Husna, "Kemampuan Literasi Informasi Siswa Sekolah Menengah Atas Kolase Loyola Semaram Ditinjau dari Prestasi Belajar," J. Ilmu Perpust., vol. 5, no. 3, 2016.

[14] C. Lee, "Worksheet Usage, Reading Achievement, Classes' Lack of Readiness , and Science Achievement: A Cross-Country Comparison," Int. J. Educ. Math. Sci. Technol., vol. 2, no. 2, pp. 96-106, 2014.

[15] D. PSMA, Panduan Implementasi Kecakapan Abad 21 Kurikulum 2013 di SMA. Jakarta: Kemendikbud, 2017.

[16] Hermawan et al., "Desain Rubrik Kemampuan Berkolaborasi Siswa SMP dalam Materi Pemantulan Cahaya," J. Penelit. Pengemb. Pendidik. Fis., vol. 3, no. 2, pp. 167-174, 2017.

[17] E. R. Lai, "Collaboration: A Literature Review," 2011. [Online]. Available: https://images.pearsonassessments.com/images/tmrs/Collaboration-Review.pdf. [Accessed: 10-Jun-2019].

[18] D. Fitriyani, T. Jalmo, and B. Yolida, "Penggunaan Problem Based Learning Terhadap Keterampilan Kolaborasi dan Berpikir Tingkat Tinggi," J. Bioterdidik, vol. 7, no. 2, pp. 93-102, 2019.

[19] M. Kundarti, A. N. Latifah, M. R. Laili, and H. Susilo, "Peningkatan Keterampilan Kolaborasi dan Literasi Digital Melalui Pembelajaran Biologi Berbasis Lesson Study Mahasiswa S1 Pendidikan Biologi UNM," in Prosiding Seminar Nasional dan Workshop Biologi IPA dan Pembelajaran, pp. 232-238, 2019.

[20] Sugiyono, Metode Penelitian Kuantitatif, Kualitatif, $R \& D$. Bandung: Alfabeta, 2016.

[21] Riduwan and Sunarto, Pengantar Statistika untuk Penelitian: Pendidikan, Sosial, Komunikasi, Ekonomi Dan Bisnis. Bandung: Alfabeta, 2012.

[22] F. K. Sari, Farida, and M. Syazali, "Pengembangan Media Pembelajaran (Modul) berbantuan Geogebra Pokok Bahasan Turunan," Al-Jabar J. Pendidik. Mat., vol. 7, 
no. 2, pp. 135-152, 2016.

[23] H. Darmadi, Metode Penelitian Pendidikan. Bandung: Alfabeta, 2011.

[24] B. B. Yusuf, "Konsep dan Indikator Pembelajaran yang efektif," J. Kaji. pembelajaran dan keilmuan2018, vol. 1, no. 2, 2018.

[25] D. PSMA, Direktorat pembinaan sekolah menengah atas direktorat jenderal pendidikan dasar dan menengah kementerian pendidikan dan kebudayaan tahun 2017. Jakarta: Kemendikbud, 2017.

[26] U. Töman, "Extended Worksheet Developed According To 5e Model Based On Constructivist Learning Approach," Int. J. New Trends Educ. Their Implic., no. October, pp. 173-183, 2013.

[27] A. P. M. Daud and Dewanto, "Impelementasi Pendekatan Ilmiah (Scientific Approach) Dalam Meningkatkan Kemampuan Kolaborasi Dan Hasil Belajar Siswa Di Smk Negeri 5 Surabaya," J. Pendidik. Tek. Mesin UNESA, vol. 5, no. 01, p. 250367, 2016.

[28] I. W. Redhana, "Model Pembelajaran Berbasis Masalah Untuk Peningkatan Keterampilan Pemecahan Masalah dan Berpikir Kritis," J. Pendidik. dan Pengajaran, vol. 46, no. 1, 2013.

[29] L. Yuliati, "Efektivitas Bahan Ajar Ipa Terpadu Terhadap Kemampuan Berpikir Tingkat Tinggi Siswa Smp,” J. Pendidik. Fis. Indones., vol. 9, no. 1, pp. 53-57, 2013.

[30] M. Coffin Murray and J. Pérez, "Unraveling the Digital Literacy Paradox: How Higher Education Fails at the Fourth Literacy," Issues Informing Sci. Inf. Technol., vol. 11, pp. 85-100, 2014. 